\title{
John Sharp Cosmati Pavements at Westminster Abbey
}

John Sharp reports on the history, meaning and execution techniques of the Cosmatesque pavements of Westminster Abby.

\section{Introduction}

Cosmati pavements are usually associated with Italy, but two of the most important ones are to be found in Westminster Abbey in London. They are both unusual and important in the history of England (Figure 1).

The Great Pavement of Westminster Abbey was laid down by Italian craftsmen in 1268 for Henry III. It has been in a very poor state of repair and kept covered by a carpet for most of the time. I also knew that there was another Cosmati pavement, but had never been able to figure out where it was. I learned, to my surprise, that it was around the shrine of Edward the Confessor and that it had been covered up with layers of sawdust and linoleum. The reason this happened was that Queen Mary (the husband of George V) and her friends were having trouble with their heels catching in it! The pavement is admirably covered in Richard Foster's book Patterns of Thought - the Hidden Meaning of the Great Pavement of Westminster Abbey. Fortunately, in the last year or so, a project has been started to repair and conserve the pavement. As part of this effort, a conference on the pavements, jointly sponsored by the Courtauld Institute and Westminster Abbey, was held in London on 7 November 1998. This conference brought together people from a wide range of disciplines, from the academic to the Guardians of the Abbey (the people who, as their name suggests, give their time to act as guides and helpers for tourists). The day consisted of three sessions of lectures, followed by a visit to the Abbey where we were allowed to walk on and examine both pavements - the crowning highlight of the day.

\section{The Visit to the Abbey}

I went to see the pavement a number of years ago on one of the few days in the year when it was visible (the pavements are uncovered only on an irregular basis). Only the Great 
Pavement could be seen on that occasion, and it was possible to walk around it but not to stand in the middle of it. This time it was possible to walk on it, touch it and look at it close up. It was exciting to feel the history under one's feet and to see the variation in workmanship and materials. What was even more interesting was to see how much more complicated it was than conventional Cosmati work (Figure 2) and to contrast it with the decoration on the tomb of Edward the Confessor and the Cosmati work in his chapel behind the altar. I knew the basic quincunx motif (Figure 3) familar in Cosmati work in Italy was central to the Great Pavement design, but it was everywhere in the Edward the Confessor chapel, from the floor to the tomb itself. I have also been familar with this design because it occurs in a famous painting that hangs in the National Gallery in London, Holbein's The Ambassadors (Figure 4) which was painted in 1533. This painting, which contains much mathematical symbolism, has the two Ambassadors standing on a pavement designed with the quincux symbol. I have studied this painting extensively, especially for the anamorphosis of the skull, on which subject I gave a lecture at the Bridges Conference in Kansas in 1998. Many references to the painting say that the Ambassadors are standing on the Great Pavement which places them in context. This is obviously not the case since the pattern is very simple in the painting. Seeing the quincunx abounding everywhere there makes me wonder what its symbolic meaning was.

\section{Number Symbolism in the Pavement's Inscription}

Although a search for symbolism in the Pavement's geometry was not undertaken in this conference, the pavement's symbolism was examined in another context. One feature of the pavement is an inscription, of which only a few letters (seven) remain. It is unusual for Cosmati pavements to have such inscriptions, although a maker's inscription is often seen. The letters were cast in a predominantly copper tin alloy. However, we do know the content of the three sections of the inscription, since they have been written down a number of times in the past. David Howlett highlighted the interesting numerology connected with the inscription, showing that a great deal of thought and scholarship had gone into its construction. Howlett set the stage for his presentation of the number symbolism in the inscription by describing number symbolism in the Old Testatment. For example, he maintained that in the Hebrew version of Genesis, God is mentioned every seventh word; certain words also divide the text into the extreme and mean ratio. There is great symmetry in the way it is written, and Howlett pointed out that the Latin translation by Jerome and Aelfric's Anglo Saxon translation kept the words balanced and exact.

The inscription as given in on p. 80 in Richard Foster's book is:

$$
\begin{gathered}
\text { +XPI MILLENO BIS CENTENO DUODENO } \\
\text { CUM SEXAGENO SUBDUCTIS QUATUOR ANNO } \\
\text { TERTIUS HENRICUS REX URBS ODORICUS ET ABBAS } \\
\text { HOS COMPEGERE PORPHYREOS LAPIDES }
\end{gathered}
$$

SI LECTOR POSITA PRUDENTER CUNCTA REVOLVAT HIC FINEM PRIMI MOBILIS INVENIET SEPES TRIMA CANES ET EQUOS HOMINESQUE SUBADDAS CERVOS ET CORVOS AQUILAS IMMANIA CETE MUNDUM QUODQUE SEQUENS PREEUNTIS TRIPLICAT ANNOS SPERICUS ARCHETIPUM GLOBUS HIC MONSTRAT MACROCOSMUM 


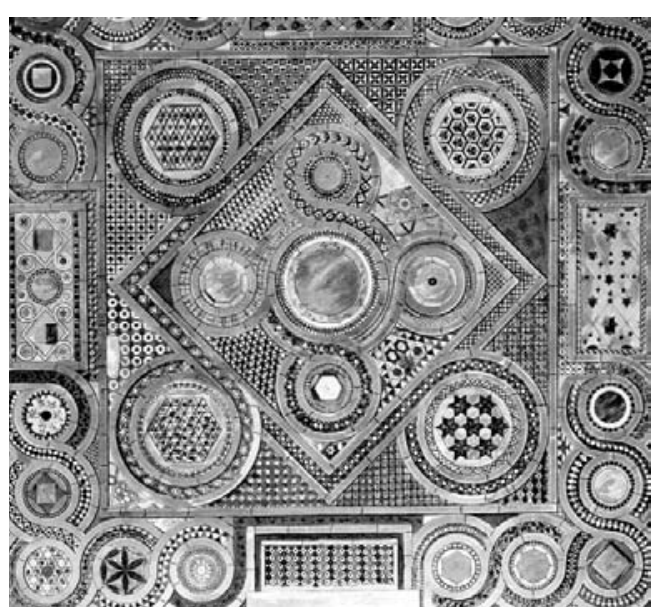

Figure 1.

1812 aquatint of the Great Pavement, Westminster Abbey.

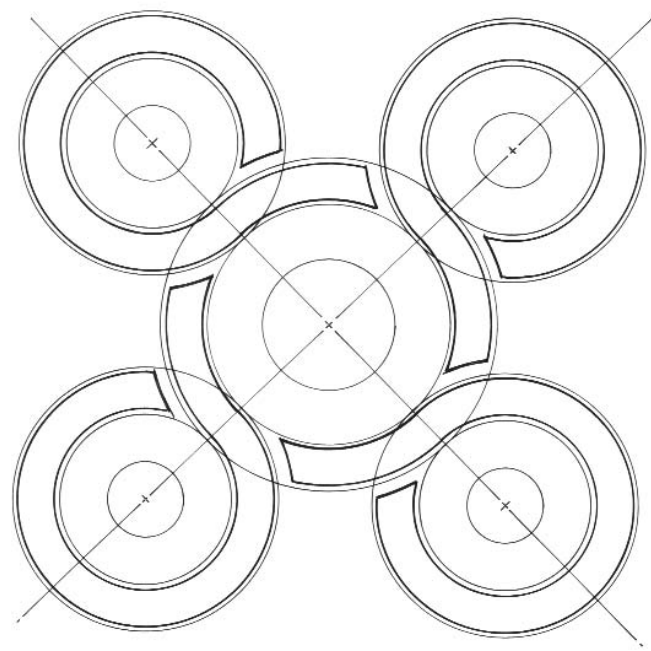

Figure 3.

Schematic geometrical drawing of the quincunx motif.

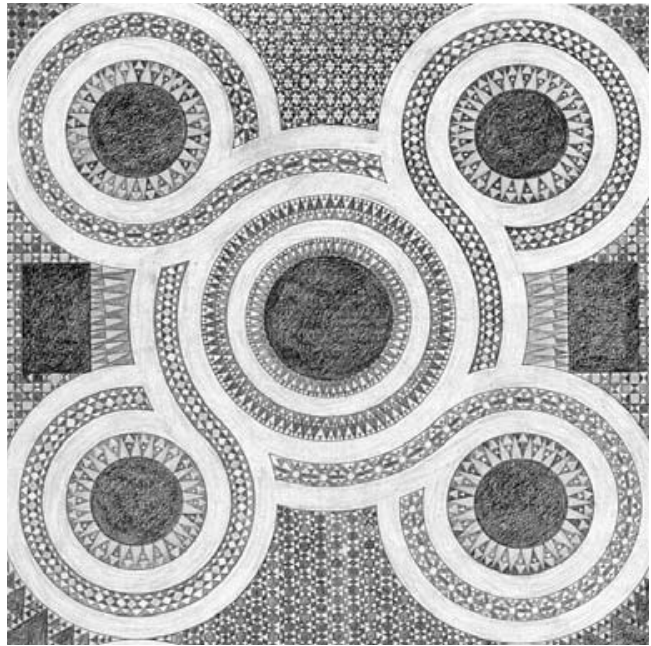

Figure 2 .

Quincunx from the church of S. Maria in Cosmedin, Rome, ca. 1123. Drawing by Kim Williams.

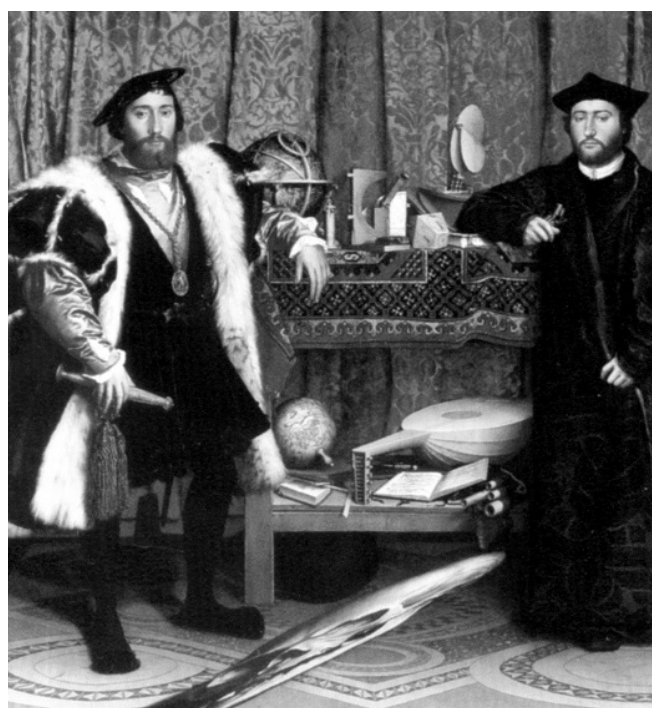

Figure 4.

Holbein's The Ambassadors. 
I have broken the lines and groups as they are constructed. The first four lines are on each of the outside sides of the pavement. The next four run around the central quincunx and the last one around the circular centre which represents the macrocosm.

There are nine lines relating to three to the power of nine, $3^{9}=19683$, which Richard Foster points out as a direct numerical counterpart to the words FINEM PRIMI MOBILIS and the ninth heavenly sphere whose end is the subject of the verse. Foster describes the neo-Platonist roots of this number three and the background to the medieval thinking in his book and that there are links to other verses at that time.

Unfortunately, David Howlett's numerical analysis, which he kept insisting was not secret but well known, doesn't always agree with my notes. So I can only present it as a puzzle which, like the curate's egg, is good in parts. Also, as long as he dealt with annotated versions of the text, his discussion was easy to follow. However, when he moved onto the inscription itself, moving very quickly and without annotations, his conclusions were difficult to confirm. My scepticism in this subject is compounded from having met such analyses before that don't quite meet deeper inspection especially when the proposer is not a mathematician.

According to Howlett there are 364 characters, thought my count is 351 . There are considerations like the XPI contraction of Christ, but this is a large discrepancy. On the link with three, the word TRIMA he says is at the Golden Section through the inscription. I count 57 words. Since my notes do not specify where the break is made, there are two possibilities. Words before are 33 , so $33 / 57$ equals 0.58 or $34 / 57$ equals 0.59 , both of which stretch the golden section hypothesis. The other numbers frequently mentioned in the discussion of the creation were 6 (the number of days to create the world) and 46. The last line, around the centre, does indeed appear to have 46 letters with six words, but his theory needs to be presented in a much more complete way in order to be convincing.

\section{The Pavements' Historical Context}

Tim Tatton-Brown introduced the pavements from the Abbey's point of view and Christopher Norton from York University set them in context with the other pavements in northern Europe.

The lesser pavement in the Confessor's Chapel is much more recognisable as Cosmati work than the Great pavement. The unusual nature of the latter lies partly in its design and partly in the materials used. Marble is not a stone that is native to the British Isles; the use of other materials which are not as resilient is one cause of the pavement's poor state of repair. The other causes are neglect and botched conservation over the last 700 years.

The lesser pavement has also been partly destroyed earlier in this century by the erection of barriers around the Coronation chair which was displayed behind the altar before the Stone of Scone was returned to Scotland. The sawdust and linoleum attracted damp and fungal growth, furthering deterioration.

There are many other decorated pavements in northern Europe ranging from figurative to geometric. No reason was given as to why there was a preponderance of geometric designs in the twelvth and thirteenth century. The Canterbury pavement was shown, as were a number of others. Unfortunately, there was little discussion about the geometry; questions of whether it had 
been moved and who was responsible were more the order of the day. There was some discussion of the way tiles took over because they were easier to make with the materials available and because colours and surface effects could be varied. Also examined was the way glass was used, especially in the Great Pavement, which features a lot of glass.

\section{Materials and Conservation}

Richard Foster expanded on his presentation of materials and conservation in his book, which has an excellent chapter on the wide range of stone and glass used. Purbeck marble (which is not a true marble) figures prominently in the pavement and there is a rangle of porphyry and limestone. Analysis of the glass suggests that they came from the same source. The potassium and sodium contents were similar as were a range of other elements.

Nicholas Durnan's description on the work he had done on the repairs and proposals for conservation was very interesting. Drawings had been prepared photogrammetrically and a painstaking identification of the individual pieces, from the level of tesserae on the band patterns for example, used to map the restoration throughout different periods. He showed how the edges were a good clue, from the crude chipping of the mediaeval craftsmen through to the the clean edges cut by the Victorian Gilbert Scott's mechanical means using a steam engine. There were also clues from the way the pattern had been matched with sensitive thought at one period and crude botching at another. Areas had been filled in with concrete.

One of the biggest problems has been the way the purbeck marble has suffered decay from moisture which, when it appears next to porphyry, has resulted in the much harder porphyry standing proud and becoming loose and having been lost in the past.

In his proposals for conservation he pointed out the problems of whether to replace or conserve. He was against taking the pavement back to the original state, since that would alter its history. But then there are the great areas of concrete and the layers of soot wax and grime which hide much of the beauty. Work has been done in some test areas and show that dramatic differences can be expected even with a minimum of cleaning. The biggest problem seems to be who will get the contract when National Lottery money is given for the cleaning and it goes out to tender. He seemed to understand not only the materials but also the environment. My worry would be if the contract was won by someone who might be used to conservation closer to the Mediterranean who did not understand these aspects and its special nature.

The final part of the third session consisted of two talks by David Carpenter on "The pavements and politics of the 1260s" and Paul Binski on "The pavements: chronology and meaning". Both talks focused on culture in the middle ages and how symbolism such as that of the pavement was important. This is underlined by the fact that the construction of the pavement went ahead despite Henry III's trouble in governing and his economic problems. As I re-entered the twentieth century at the end of this enjoyable day, I pondered on how many people in our own age are as in touch with the sense of wonder at the world as the designers and craftsmen who built these marvelous pavements. 


\section{Bibliography}

JANE FaWCETT, ed. Historic Floors: Their History and Conservation. Butterworth-Heinemann Series in Conservation and Museology. Oxford: Butterworth-Heineman, 1998.

Richard Foster. Patterns of Thought. The Hidden Meaning of the Great Pavement of Westminster Abbey. London: Jonathan Cape, 1991.

JoHn SHARP, "Problems with Holbein's Ambassadors and the Anamorphosis of the Skull," Bridges: Mathematical Connections in Art, Music and Science. Proceedings of the 1998 Bridges Conference. Reza Sarhangi, ed. Winfield, Kansas: Southwestern College, 1998.

KIM Williams. Italian Pavements: Patterns in Space. Houston: Anchorage Press, 1998.

\section{About the author}

John Sharp has researched and taught Geometry and Art for over 20 years in Adult Education in and around London. He is the illustrator of David Well' Penguin Dictionary of Curious and Interesting Geometry and has written his own book, Sliceforms, on modelling geometrical surfaces. Some of these surfaces were in the 1999 "Strange Surfaces" exhibit in the Science Museum in London. 